ZOOLOGIA 32(5): 395-402, October 2015

http://dx.doi.org/10.1590/S1984-46702015000500008

\title{
Histological and immunohistochemical study of the ovaries and oviducts of the juvenile female of Caiman latirostris (Crocodilia: Alligatoridae)
}

\author{
Clarice Machado-Santos ${ }^{1, *}$, Lailah N. de S. Santana', Rosilene F. Vargas ${ }^{2}$, \\ Marcelo Abidu-Figueiredo', Lycia de Brito-Gitirana ${ }^{3} \&$ Maurício A. Chagas ${ }^{1}$
}

\author{
'Universidade Federal Fluminense, Instituto Biomédico. Rua Professor Hernani Melo, São Domingos 24210-130 Niterói, RJ, Brazil. \\ 2Programa de Pós-graduação em Biologia Animal, Universidade Federal Rural do Rio de Janeiro. Rodovia BR465, km 7, \\ 23851-970 Seropédica, RJ, Brazil. \\ ${ }^{3}$ Laboratório de histologia integrativa, Instituto de Ciências Biomédicas. Universidade Federal do Rio de Janeiro. Avenida \\ Trompowsky, bloco B1-017, Ilha do Fundão, 21970-540 Rio de Janeiro, RJ, Brazil. \\ “Corresponding author. E-mail: claricemachado@id.uff.br
}

\begin{abstract}
The purpose of this study was to examine the ovaries and the oviduct of juvenile females of the broadsnouted caiman, Caiman latirostris (Daudin, 1802), using light microscopy, histochemical and immunocytochemical techniques. The ovarian cortex was observed to contain groups of germinative cells and abundant previtellogenic follicles at different stages of development. In previtellogenic follicles, the oocyte was surrounded by a single cuboidal layer of granulosa cells, supported by the theca layer. The theca was formed by a concentric layer containing collagenous fibers, predominantly type I, and several smooth muscle fibers. The inner perivitelline layer appeared as a narrow basophilic region between the oocyte and the granulosa. The ovarian medullary region of loose connective tissue contained blood and lymphatic vessels, as well as numerous lacunae, being covered by a simple squamous epithelium, supported by a thin layer of connective tissue. The oviduct of $C$. latirostris showed five histologically distinct regions: infundibulum, magnum, isthmus, uterus and vagina. The infundibulum was composed of an irregularly folded mucosa covered by a simple columnar epithelium with the presence of ciliated cells, weakly reactive to PAS staining. In the magnum, the mucosa was highly folded, and pseudostratified columnar epithelium contains mucous cells, which reacted positively to PAS staining. The isthmus was lining by an epithelium of ciliated and non-ciliated secretory cells, but no gland was visualized in mucosa. In the uterus, the folded mucosa was composed of a simple epithelium of high cylindrical cells and the lamina propria, which was predominantly formed by strongly birefringent fibers, but yellow-green weakly birefringent fibers were also present. The epithelium of the vagina contained intensely ciliated and non-ciliated cells, both of which were positive to PAS staining and no gland was observed in this region. Although the ovary and the oviduct showed some morphological particularities, they are similar to other crocodilians.
\end{abstract}

KEY WORDS. Female reproductive system; morphology; reptiles.

Crocodiles are reptiles that belong to the order Crocodilia, which is divided into two families: Alligatoridae and Crocodylidae. Five species can be found in Brazil: Caiman latirostris (Daudin, 1802), broad-snouted caiman, Melanosuchus niger (Spix, 1825) (black caiman), Paleosuchus palpebrosus (Cuvier, 1807) (dwarf caiman), Caiman crocodilus crocodilos (Linnaeus, 1758) (common caiman) and Caiman crocodilus yacare (Daudin, 1802) (yacaré caiman), all belonging to the family Alligatoridae (IUCN 2015).

Broad snouted caimans are widely distributed in South American aquatic ecosystems (Yanosky 1990, Verdade 1995). Caimans spend a large portion of their lives in the water. They are long-lived animals and are at the top of the food chain. As in other countries, the broad-snouted caiman was placed in the endangered species list of Brazil, since populations are low due to habitat pollution and predatory hunting for commercial purposes (Bernardes et al. 1990, GRoOMBridge 1987). Caiman latirostris is still included in listed on CITES Appendix I (except the population of Argentina) that include all species threatened with extinction, which are or may be affected by trade (IUCN 2015). Because of its economic potential (for leather and meat) there has been great interest in recent years in its commercial breeding (AvEIRo 2012).

In the oviduct of reptiles, five regions are recognized: infundibulum, magnum, isthmus, uterus and vagina (GIRLING 2002). Crocodilians are unusual reptiles in that there are two separate regions, one for formation of the eggshell membranes and the other for the calcareous layer (PALmer \& Guillette 1992). 
In this respect, these animals are similar to birds, in which a soft shell membrane is formed in the isthmus and the calcareous shell is formed in the uterus (AL-KINDI et al. 2006).

Various articles have described the oogenesis process and histology of the ovaries and oviducts of reptiles, such as of the species Mabuya brachypoda (Taylor, 1956) (Hernandez-Franyutti et al. 2005), Sceloporus grammicus (Weigmann, 1828) (Lozano et al. 2014), sea turtles of the species Caretta caretta (Linnaeus, 1758), Dermochelys coriacea (Vandelli, 1761) and Chelonia mydas (Linnaeus, 1758), (CERIANIA \& WYNEKEN 2008), the freshwater turtles Chelydra serpentina (Linnaeus, 1758) (AL-Kindi et al. 2006) and Phrynops geoffroanus (Schweigger, 1812) (Firmiano et al. 2012) and the snack Naja kaouthia (Lesson, 1831) (TumkiRaTIwong et al. 2012). In crocodilians, the reproductive system has been described of Alligator mississippiensis (Daudin, 1802) (Joss 1989, Guillette et al. 1994, 1995, 1997, Uribe \& Guillette 2000), Caiman crocodilus (Linnaeus, 1758) (CALDERón et al. 2004) and Caiman yacare (Coutinho et al. 2005). In C. latirostris, Verdade (1995) described the reproductive biology of males and females and STOKER et al. $(2003,2008)$ reported alterations in the follicular dynamics and steroid levels caused by exposure to endocrine disruptor chemicals (EDCs).

The reproductive cycle of crocodilians is more complex and evolved than in other reptiles. In general, caimans, alligators and the smaller crocodile species reach sexual maturity while still relatively small in relation to their full adult size, while the large crocodile species only become sexually mature when they reach relatively larger sizes (MAGNusson et al. 1989). Female broadsnouted caimans take seven to eight years to reach reproductive maturity and males take 10 years. In C. yacare, the vitellogenic capacity can start earlier, at around 5 years of age, but mature ovaries with advanced vitellogenic follicles have only been observed in 7-year old females (CoutinHo et al. 2005).

Knowing the reproductive biology of an animal is a key factor to achieve success in its long-term rearing. The objective of this study was to characterize the structure of the ovaries and oviducts of the juvenile female Caiman latirostris through histochemical and immunohistochemical techniques. This new information increases our understanding of the morphological changes during puberty, thereby enhancing the breeding of this commercially valuable reptile.

\section{MATERIAL AND METHODS}

Eight two-year old juvenile females of Caiman latirostris, from Bonsucesso Farm (Nossa Senhora do Amparo District of Barra Mansa City, Rio de Janeiro State, Brazil), were obtained after slaughter at a slaughterhouse located near the city of Itaguai. The breeder is registered in accordance with the Brazilian environmental agency (IBAMA) and is authorized by the local government (Rio de Janeiro State Environmental Agency, FEEMA) and regional board of veterinary medicine. The animals were subjected to hypothermia prior to being slaughtered after exsanguination.
For the light microscopy study, we removed from each animal three ovary samples and one sample from each region of the oviduct (infundibulum, magnum, isthmus, uterus and vagina). The fragments were collected and fixed by immersion in Bouin's liquid for six hours. The samples were then processed according to the histological technique for paraffin embedding. Five-micrometer-thick serial slices were stained with hematoxylin-eosin and Gomori's trichrome (LiLLIE \& FULLMER 1976) to analyze the general morphology and the arrangement of collagenous fibers. The Weigert's resorcin-fuchsin staining was used to visualize the elastic fiber system (Lillie \& Fullmer 1976). Staining with 1\% Alcian blue (AB) 8GX at pH 2.5 (Kiernan 1990) was employed to detect sulfated and carboxylated acidic glycoconjugates. The periodic acid and Schiff reagent (PAS) staining was employed to detect neutral glycoproteins. Moreover, the picrosirius-polarization method (JunQUeIRA et al. 1979) was utilized to observe the arrangement of collagenous fibers.

For immunohistochemistry, paraffin sections were dewaxed, dehydrated and washed in phosphate buffered saline (PBS), followed by incubation with methanol containing 0 $3 \% \mathrm{H}_{2} \mathrm{O}_{2}$ for 15 minutes to block any endogenous peroxidase. The sections were then incubated with a 1:100 dilution of bovine serum albumin (B4287; Sigma) in phosphate buffered saline (PBS) in a humid chamber for 30 minutes at room temperature, followed by incubation overnight with antismooth muscle á actin (Cat. no. 08-0106, Zymed, California, USA) diluted to $1: 200$ at $4^{\circ} \mathrm{C}$. Sections were then incubated with biotinylated secondary antibody (PK 7200, Vector Laboratories, Inc., U.K.) for 30 minutes, then with $\mathrm{ABC}$, diluted to 1:200, for 30 minutes (both from PK 6200, Vector Lab. Inc.). Subsequently, the peroxidase label was revealed by reaction with $\mathrm{DAB}$ at room temperature before dehydration and mounted using Enthelan (Merck).

Oocytes and follicles were classified according to previously established criteria for $A$. mississippiensis and C. crocodilus (Uribe \& Guillette 2000, Calderón et al. 2004). In the stages I and II (or early previtellogenesis) oocyte growth is initiated and in stage III follicles are in advanced stages of previtellogenesis. To quantify the diameter of the oocytes of the ovarian follicles three sections of each animal were digitized. Selected images used for measurements and quantification were obtained using a light microscope (Leica DM500) coupled to a Digital Camera Leica ICC50 HD. Image analysis was carried out using the Image J system (National Institute of Health, EUA).

\section{RESULTS}

The ovaries of juvenile females of the $C$. latirostris are characterized by an irregularly shaped, elongated structure, and present a cortical and a medullar region (Fig. 1). The cortical region is covered by an epithelium that varies from cuboidal simple to squamous. Below the epithelium a thin tunica albuginea is formed by dense unordered connective tissue, revealed 
by Gomori's trichrome (Fig. 1). Staining with picrosirius red revealed red strongly birefringent fibers, indicating the predominance of type I collagen (Fig. 2). In the tunica albuginea, thin smooth muscle fibers were also observed, detected by the immunohistochemical method for á-smooth muscle actin (SMA).
The ovarian cortex was observed to contain groups of germinative cells and abundant previtellogenic follicles at different developmental stages, along with sparse follicles in the initial stage of development (stage I). These contained an oocyte surrounded by squamous follicular cells.
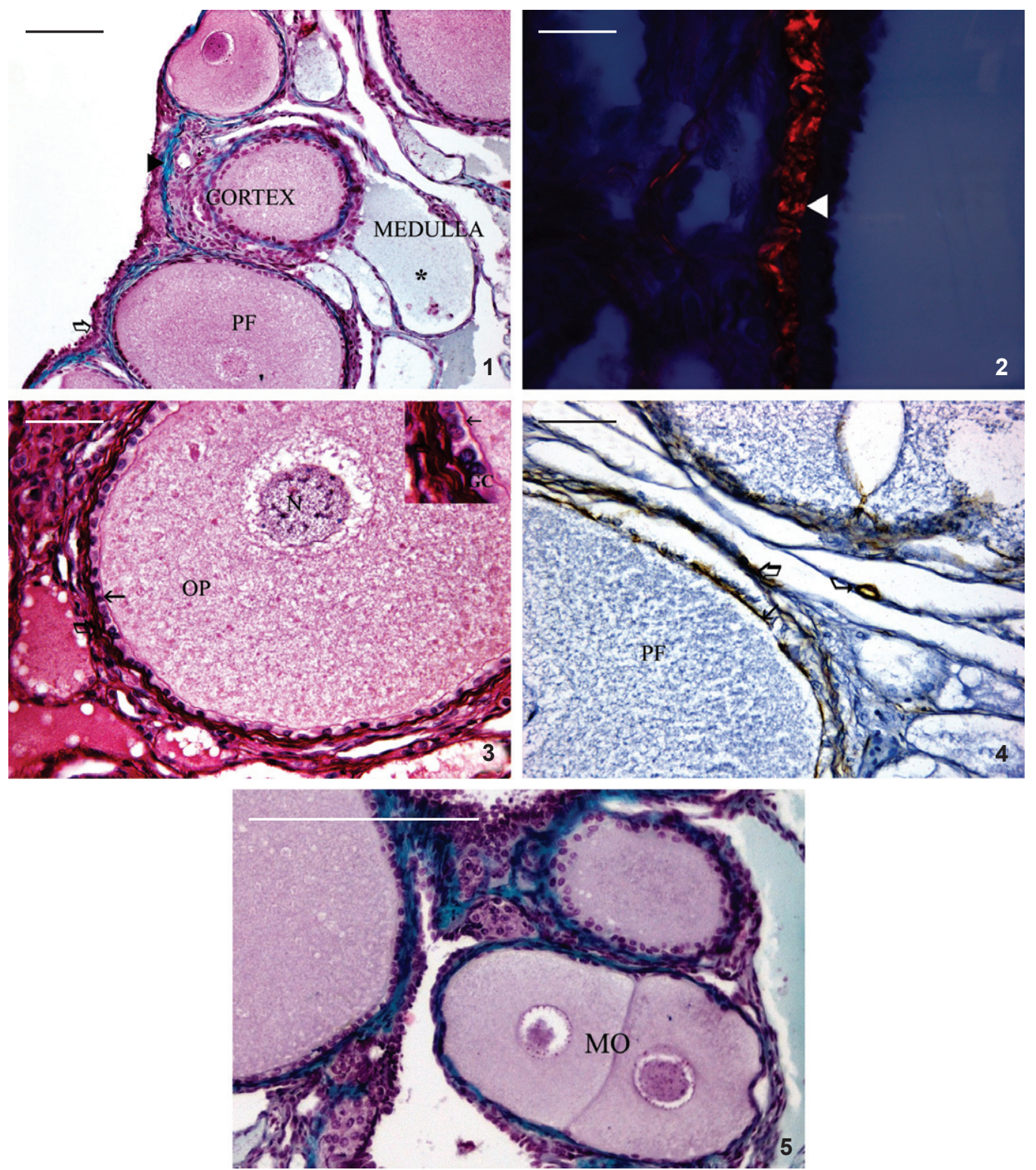

Figures 1-5. Photomicrographs of a cross section of the ovary of Caiman latirotris. (1) Cortical region with previtellogenic follicles (PF) and a medullar region with lacunae covered by a simple squamous epithelium $\left(^{*}\right)$. The ovarian surface epithelium ( $\Rightarrow$ ), tunica albuginea $(\triangleright)$. Gomori's trichrome. (2) Tunica albuginea formed by strongly birefringent fibers $(\triangleright)$, indicating the predominance of type I collagen. Picrosirius red. (3) Previtellogenic follicles (stage III). Oocyte nucleus (N) and ooplasm (OP). The oocyte is surrounded by a single cuboidal layer of granulosa cells (GC), supported by a theca layer $(\hookrightarrow)$ ). Note the presence the inner perivitelline layer $(\leftarrow)$. Picrosirius red. (4) Smooth muscle cells in blood vessel walls $(\neg)$ and in theca layer $(\neg)$. Note positive reaction in the inner perivitelline layer $(\leftarrow)$. (5) Previtellogenic follicles containing multiple oocytes (MO). Gomori's trichrome. Scale bars: $1=100 \mu \mathrm{m}, 2=20 \mu \mathrm{m}, 3-4=50 \mu \mathrm{m}, 5=200 \mu \mathrm{m}$. 
Follicles in stage II had diameters ranging from 0.12 to $0.15 \mathrm{~mm}$, with large nuclei, and were completely surrounded by squamous to cuboidal follicular cells. Follicles in advanced stages of previtellogenesis (stage III) measured between 0.33 and $0.43 \mathrm{~mm}$ in diameter and contained oocytes immersed in abundant follicular liquid. The nucleus of the oocyte is oval, eccentric or central, and contains lampbrush chromosomes and nucleoli. The ooplasm contains small uniformly distributed vacuoles. The oocyte is surrounded by a single cuboidal layer of granulosa cells, supported by a theca layer (Fig. 3). The theca is formed by a concentric layer of collagenous fibers, predominantly type I (Fig. 3), and several smooth muscle fibers (Fig. 4). With increased follicular size, the inner perivitelline layer (Fig. 3), which is equivalent to the zona radiate, appears like a narrow basophilic band established in the border region between oocyte and granulosa cells. This region was positive for SMA immunohistochemical method (Fig. 4). Previtellogenic follicles containing multiple oocytes were observed (Fig. 5). Vitellogenic follicles, atresic follicles and corpus luteum were not identified.

The ovarian medullary region is composed of loose connective tissue with blood and lymphatic vessels, as well as numerous lacunae covered by a simple squamous epithelium, supported on a thin layer of connective tissue, hence classified as a chordolacunar type ovary. The lacunae contain an acidophilic substance (Fig. 1). No elastic system fibers were observed in the ovarian stroma.

The oviduct of the C. latirostris juvenile females presented the same five histologically distinct regions as other reptiles: infundibulum, magnum, isthmus, uterus and vagina, all of them formed by three concentric layers: mucosa, muscular and serosa (Fig. 6).

The infundibulum is composed of an irregularly folded mucosa covered by a simple columnar epithelium with the presence of ciliated cells, weakly reactive to PAS staining. The lamina propria presents small simple tubular glands without the presence of acid of neutral mucins (AB and PAS negative, respectively) and dense unmodeled connective tissue. The muscular layer is formed by two layers of smooth muscles.

In the magnum, the mucosa is highly folded. The epithelium lining is pseudostratified columnar and contains cells with characteristics of mucosa cells, which react positively to PAS staining, demonstrating the presence of neutral glycoproteins (Fig. 7). Intraepithelial glands were present. The lamina propria has varied small glands (tubulo-alveolar, branched tubular and branched acinar) that are PAS negative. The lamina propria contains smooth muscles. The muscle layer is formed by smooth muscle tissue with a circular internal and longitudinal external arrangement and the serosa was clearly visible, with the presence of a mesothelium formed by a simple squamous epithelium (Fig. 8).

The isthmus is an intermediate area between the magnum and uterus. It presents an epithelium composed of cili- ated and non-ciliated secretory cells, but contains no glands in its mucosa. The other layers of the isthmus have similar form to those of the other regions.

In the uterus, the epithelium is formed by high cylindrical cells with basal nuclei and the mucosa is folded (Fig. 9). The lamina propria is predominantly formed by strongly birefringent fibers stained red by the picrosirius method, but yellow weakly birefringent fibers are also present. This region has small glands in the lamina propria (Fig. 10). The muscles are formed by two layers, one internal circular and the other external longitudinal, which is thicker.

The most caudal region of the oviduct, which leads out to the common urogenital or cloacal opening, is called the vagina. The epithelium contains intensely ciliated cells as well as non-ciliated cells, both of which are positive to PAS staining. No glands were observed in this region. The muscles are formed of two smooth muscle layers.

\section{DISCUSSION}

The gonadal histoarchitecture of the non-reproductive C. latirostris females examined was similar to that of other crocodilians, such as C. crocodilus (CALDERón et al. 2004) and $A$. mississippiensis (URIBE \& GuIlLetTe 2000). The chordolacunar type ovary has also been described in birds and testudines (CALLEBaut 1988, CERIANI \& WYNEKEN 2008). This type of ovary is characterized by the presence of various medullary lacunae that support the developing follicles, with the necessary expansive properties during follicular development. These may also participate in ovulation (CALlebaut 1988).

The epithelium of the ovaries examined is cuboidal to squamous and contains dense connective tissue and small bundles of smooth muscle, constituting the thin ovarian wall or tunica albuginea. CALDERÓN et al. (2004) using ultra-thin sections identified fibers of elastin lamina underline the epithelium of $C$. crocodiles. However, these fibers were not observed in our study using the staining with Weigert's resorcinfuchsin.

The germinative cells were found in the cortical ovary of C. latirostris. These cells were also identified in C. crocodilus (CALderón et al. 2004) and the neonatal ovary of C. latirostris (STOKER et al. 2008). It is widely accepted that after birth the primordial germ cells of mammals do not proliferate. Thus, it is the ovarian reserve of primordial follicles that comprises the source of female gametes for life (VAN Voorhis 1999). In many reptiles, it is known that oogonia proliferation occurs in the gonad during embryonic development and continues in adulthood (LESSMAN 1999). However, mitotic figures were frequently seen in germ cells in neonatal and 3-monthold C. latirostris (StOKER et al. 2008).

Previtellogenesis is a stage of development that involves emergence of a variety of follicles, ranging from primordial follicles that have recently migrated out of the germinal bed to large follicles immediately prior to vitellogenesis (VIEIRA et al. 


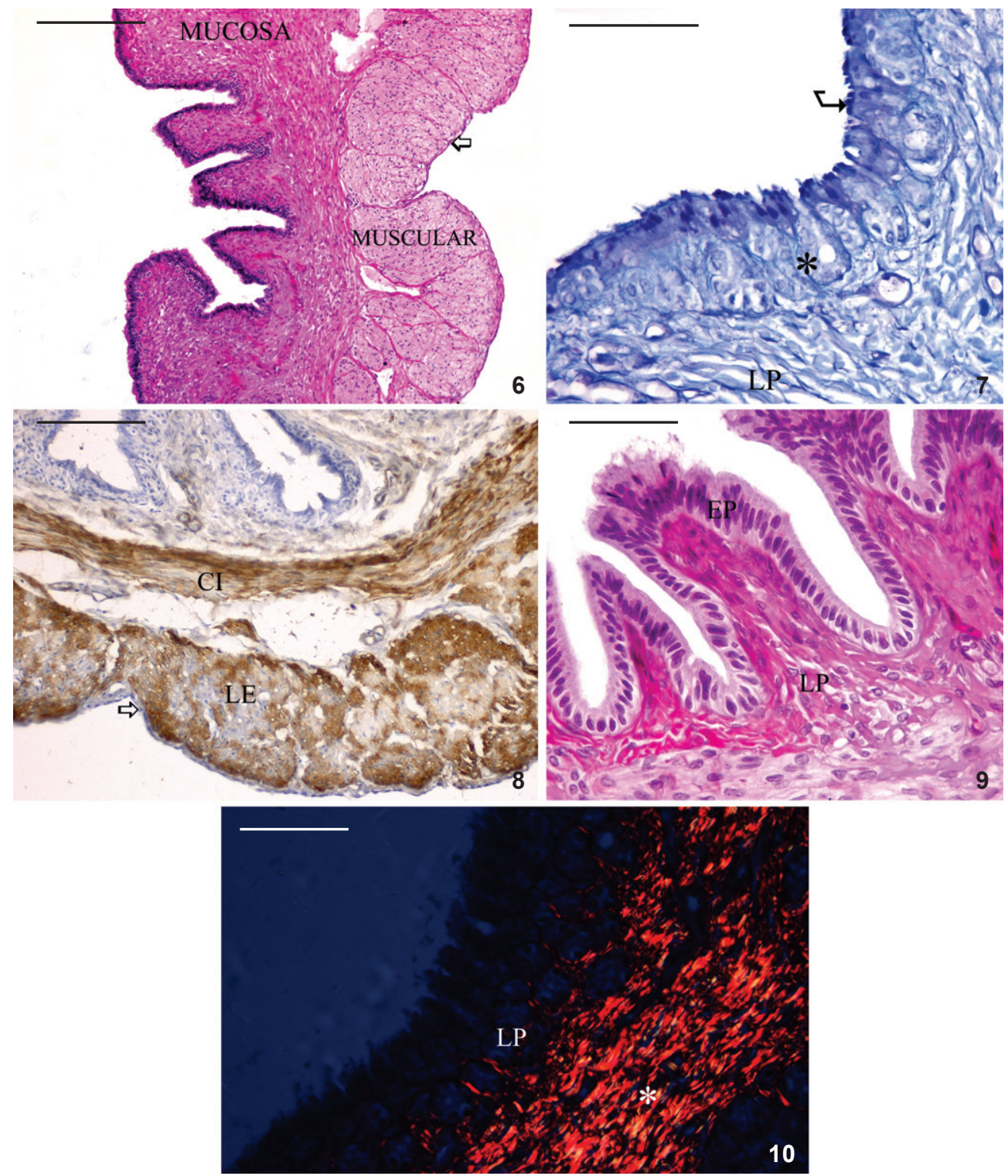

Figures 6-10. Photomicrographs of a cross section of the oviduct of Caiman latirotris. (6) The infundibulum with three concentric layers: mucosa, muscular and serosa ( $)$ ). Hematoxylin and eosin. (7) Magnum lining by pseudostratified columnar epithelium. Note mucosa cells, which react positively to PAS staining (arrow) and intraepithelial glands ( ${ }^{*}$ ). Lamina propria (LP). AB pH 2.5. (8) Smooth muscle cells in magnum. Muscle layer formed by smooth muscle tissue with a circular internal (CI) and longitudinal external (LE) arrangement and the serosa (arrow).(9) Uterus with folded mucosa and epithelium formed by high cylindrical cells. The lamina propria (LP). Hematoxylin and eosin. (10) Uterus. The lamina propria is predominantly formed by strongly birefringent fibers $\left({ }^{*}\right)$ stained red by the picrosirius method. Note small glands in the lamina propria (LP). Scale bars: $6=200 \mu \mathrm{m}, 7,9,10=50 \mu \mathrm{m}, 8=100 \mu \mathrm{m}$.

2010). The previtellogenic follicles of $C$. latirostris are abundant and contain a nucleus, ooplasm and a layer of follicular or granulosa cells. Three types of follicular cells (pyriform cells) were observed in the snake N. kaouthia (Tumkiratiwong et al. 2012). In C. latirostris, the granulosa is a single layer, like in birds (GURAYA
1989), C. crocodilus (CALderón et al. 2004) and A. mississippiensis (Lance 1989, Uribe \& Guillette 2000). These granulosa cells are apparently involved in the early steps in oocyte development. As the time of ovulation approaches, granulosa cells and some thecal cells accumulate cholesterol-positive lipids, and follow- 
ing ovulation, proliferate and luteinize to form the corpora luteum (Norris 2007, Tumkiratiwong et al. 2012). The follicular diameters in the previtellogenic C. latirostris specimens ( 0.12 to $0.43 \mathrm{~mm}$ ) were similar to those observed in C. crocodilus ( 0.15 to $0.39 \mathrm{~mm}$ ) (CALDERón et al. 2004).

Distinct immunostaining for á-smooth muscle actin was regularly found in the follicular walls of the previtellogenic follicles of $C$. latirostris. The presence of smooth muscle fibers outlining the theca of vitellogenic follicles, in the chordae that suspend the follicles, and below the ovarian epithelium was observed in C. crocodilus (CALDERón et al. 2004). Jones (1987), studying scaled reptiles, VAN NASSAUW et al. (1991), analyzing testudines, and CALDERón et al. (2004), studying alligators, all suggested the participation of these structures during follicular development and ovulation processes, through contractile mechanisms.

In the corpora luteum, follicular atresia and formation of the corpora atretica follicles are common elements in reptilian ovaries, as in other vertebrates (NoRRIS 2007). However, as in juvenile females of $C$. crocodilus (CALDERón et al. 2004), these structures were not detected in $C$. latirostris. This absence is due to the fact that these structures are reported only in reproductive females.

The reptilian oviduct is an organ whose multiple functions reflect the variety of reproductive patterns exhibited by diverse group of animals (GIRLING 2002). In reptiles, the term 'oviducts' designates the structures derived from the Müllerian ducts in the embryonic period (WAKE 1985). The oviduct in reptiles is divided into five anatomical regions: infundibulum, magnum, isthmus, uterus and vagina (Fox 1977, GIRLING 2002). However, the different regions are not recognized in all reptilian species, and additional regions may also be included, like in the oviparous lizards Crotaphytus collaris (Say, 1823) and Eumeces obsoletus (Baird \& Girard, 1852) (Guilletre et al. 1989), the viviparous lizard Hoplodactylus maculatus (Gray, 1845) (GIRLING et al. 1997), the snakes Diadophis punctatus (Linnaeus, 1766) (Perkins \& Palmer 1996) and Seminatrix pygaea (Cope, 1871) (SEVEr et al. 2000), in gecko Hemidactilus mabouia (Moreau De Jonnès, 1818) (NogueIra et al. 2011).

The oviduct of $C$. latirostris shows the same histological layers found in other species of reptiles, like the turtles $P$. geoffroanus (Firmiano et al. 2012) and C. serpentina (Al-Kind et al. 2006) and lizards C. collaris and E. obsoletus (GuilLette et al. 1989). From the outer surface to the lumen, these are as follows: serosa, muscle and mucosa.

In the infundibulum of $C$. latirostris, the mucosa contains folds that gradually increase in height toward the magnum, as in the gecko Hemidactylus turcicus (Linnaeus, 1758) (GIrLING et al. 2000) and in snake D. punctatus (Perkins \& Palmer 1996). The infundibulum contains a simple ciliated columnar epithelium, in contrast to that found in P. geoffroanus (Firmiano et al. 2012), which reacts negatively to PAS. In C. latirostris the epithelial cells react positively, indicating neutral glycoconjugates. Like in C. serpentine (AL-KINDI et al. 2006), in C. latirostris we only observed a few scattered endometrial glands in the lamina propria.

The magnum of turtles and crocodilians is responsible for the production of albumen: egg white proteins that surround the egg prior to oviposition in turtles and crocodilians, but not in squamates (Girling 2002). The magnum of $C$. latirostris is highly pleated and the mucosa has high longitudinal elevations, as described in C. serpentina (AL-KINDI et al. 2006). The pseudostratified columnar epithelium of the tube of $C$. latirostris responds positively to PAS staining, indicating the production of neutral glycoconjugates, a result also found in D. punctatus (Perkins \& Palmer 1996), H. turcicus, Saltuarius wyberba (Couper, Schneider \& Covacevich, 1997) and $H$. maculatus (GirLING et al. 1998), and H. mabouia (GirLING et al. 2000). This secretion may be involved in protecting and lubricating epithelial surfaces, thereby facilitating the passage of oocytes through the oviduct (SEver et al. 2000, GirLing et al. 2000). In female C. latirostris specimens, we observed only small endometrial glands in the lamina propria. However, the endometrial glands are numerous and occupy most of the lamina propria in C. serpentina (AL-KINDI et al. 2006) and P. geoffroanus (FIrmiano et al. 2012). These differences can be explained by the fact that the females examined in this study had not yet reached reproductive age.

The isthmus is narrow and connects the magnum with the uterus. The isthmus often appears to share similarities with both its neighboring regions (GIRLING 2002). Few glands are found in the mucosa of C. serpentina (AL-KINDI et al. 2006). However, in C. latirostris no glands were found.

The uterine mucosa of $C$. latirostris is pleated, as observed in C. serpentina (AL-KINDI et al. 2006). The luminal epithelium in C. latirostris is similar to that of oviparous squamates, composed by a columnar epithelium with both ciliated and nonciliated cells (Palmer et al. 1993, Perkins \& Palmer 1996, GIRLING et al. 1998). The lamina propria of C. latirostris predominantly contains collagenous fibers and small glands. In C. serpentina (AL-KINDI et al. 2006), the endometrial glands dominate the lamina propria. A thick muscular wall with an outer longitudinal and inner circular layer was observed, like in the turtle $P$. geoffroanus (Firmiano et al. 2012).

The mucosa epithelium of the vagina is composed of ciliated and non-ciliated cells. Sever et al. (2000) suggested that ciliated cells may function in sperm transport or the movement of mucus and debris from the oviduct. On the other hand, non-ciliated cells, which stain positively for carbohydrate substances, contain numerous secretory granules (GIRLING et al. $1997,1998)$. In the common gecko, H. maculatus, goblet cells were also present, but in C. latirostris this cell type was not observed. In the vagina of $P$. geoffroanus (Firmiano et al. 2012), glands or gland-like crypts between the mucosal folds can be present in the anterior vagina and are associated with sperm storage, but in C. latirostris these glands were not observed. 
The morphology of the ovaries of juvenile females of $C$. latirostris is similar to that of other species of crocodilians, for instance C. crocodilus and A. mississippiensis, which includes follicular histological features and a well-developed chordolacunar system. However, despite numerous studies on the oviducts of reptiles, more studies in crocodilians are needed to clarify their morphology as well as their reproductive cycles.

\section{ACKNOWLEDGMENTS}

We thank Dr. Glenn Collard of Bonsucesso Farm (Nossa Senhora do Amparo, Barra Mansa, RJ) for supplying the animals studied here, and Diogo Marcus Leibão Salles of Acquanature for use of the abattoir facilities. Funding was provided by the National Council for Technological and Scientific Development (CNPq) and Rio de Janeiro State Research Foundation (FAPERJ).

\section{LITERATURE CITED}

Al-Kindi AYA, Mahmoud Y, Woller MJ, Plude JL (2006) Oviductal morphology in relation to hormonal levels in the snapping turtle, Chelydra serpentine. Tissue and Cell 38(1): 19-33. doi: 10.1016/j.tice.2005.10.001

Aveiro AVD (2012) Criação de jacaré em cativeiro. Curitiba, Instituto de Tecnologia do Paraná, Boletim técnico 26.

Bernardes AT, Machado ABM, Rylands AB (1990) Fauna Brasileira Ameaçada de Extinção. Brasília, IBAMA, 65p.

Calderón ML, Pérez RG, Pinilla MPL (2004) Morphology of the ovary of Caiman crocodilus. Annals of Anatomy 186(1): 13 24. doi: 10.1016/s0940-9602(04)80113-4

Callebaut M (1988) The ovarian chordolacunar system in birds. Archives De Biologie 99: 1-15.

Ceriani SA, WyneKen J (2008) Comparative morphology and sex identification of the reproductive system in formalinpreserved sea turtle specimens. Zoology 111(3): 179-187. doi: 10.1016/j.zool.2007.07.007

Coutinho M, Campos Z, Cardoso F, Martinelli P, Castro A (2005) Ciclo reprodutivo de machos e fêmeas de Jacaré-do-Pantanal, Caiman crocodilus yacare. Corumbá, Comunicado técnico Embrapa.

Firmiano EMS, Cardoso NN, Santos MAJ, Sousa BM, Nascimento AA, Pinheiro NL (2012) Histology and Histochemistry of the Oviduct of the Neotropical Tortoise Phrynops geoffroanus (Schweigger, 1812). Journal of Cytology \& Histology 3(7): 1-8. doi: 10.4172/2157-7099.1000164

Fox H (1977) The urogenital system of reptiles, p. 1-157. In: Gans C (Ed). Biology of the reptilian. New York, Academic Press, vol. 6.

GIRLING JE (2002) The reptilian oviduct: A review of structure and function and directions for future research. Journal of Experimental Zoology 293(1): 141-170.

Girling JE, Cree A, Guillette Jr LJ (1997) Oviductal structure in a viviparous New Zealand gecko, Hoplodactylus maculatus. Journal of Morphology 234(1): 51-68. doi: 10.1002/ (SICI)1097-4687(199710)234:1<51::AID-JMOR5>3.0.CO;2-Q Girling JE, Cree A, Guillette Jr LJ (1998) Oviductal structure in four species of gekkonid lizard differing in parity mode and eggshell structure. Reproduction, Fertility, and Development 10(2): 139-154. doi: 10.1071/R97056

Girling Je, Guillette Jr LJ, Cree A (2000) Ultrastructure of the uterus in an ovariectomized gecko (Hemidactylus turcicus) after administration of exogenous estradiol. Journal of Experimental Zoology 286(1): 76-89. doi: 10.1002/ (SICI)1097-010X(20000101)286:1<76::AID-JEZ7>3.0.CO;2-3

Groombridge B (1987) The distribution and status of world crocodilians, p. 9-21. In: WebB GJW, Manolis SC, WhitehEAD PJ (Eds.). Wildlife Management: Crocodiles and Alligators. Chipping Noton, Surrey Beatty \& Sons, 552p.

Guillette Jr LJ, Fox SL, Palmer BD (1989) Oviductal morphology and egg shelling in the oviparous lizards, Crotaphytus collaris and Eumeces obsoletus. Journal of Morphology 201(2): 145159. doi: $10.1002 /$ jmor. 1052010205

Guillette Jr LJ, Gross TS, Masson GR, Matter JM, Percival hF, WoodWARD AR (1994) Developmental abnormalities of the gonad and abnormal sex hormone concentrations in juvenile alligators from contaminated and control lakes in Florida. Environmental Health Perspectives 102(8): 680688.

Guillette Jr LJ, Woodward AR, Qui YX, Cox MC, Matter JM, Gross TS (1995) Formation and regression of the corpus luteum of the American alligator (Alligator mississippiensis). Journal of Morphology 224(1): 97-110. doi: 10.1002/ jmor.1052240111

Guillette Jr LJ, Woodward AR, Crain DA, Masson GR, Palmer BD, Cox MC, You-Xiang Q, Orlando EF (1997) The reproductive cycle of the female American alligator (Alligator mississippiensis). General and Comparative Endocrinology 108(1): 87-101. doi: 10.1006/gcen.1997.6953

Guraya SS (1989) Ovarian Follicles in Reptiles and Birds. Berlin, Springer-Verlag, 287p.

Hernandez-Franyutti A, Uribe MC, Guillette LJ (2005) Oogenesis in the viviparous matrotrophic lizard Mabuya brachypoda. Journal of Morphology 227(2): 67-79. doi: 10.1002/ jmor. 10347

IUCN (2015) The IUCN Red List of Threatened Species. Version 2015.1. Available online at: http://www.iucnredlist.org [Acsessed: 01/06/2015]

Jones RE (1987) Ovulation: insights about the mechanisms based on a comparative approach, p. 203-240. In: NorRIS DO, JONES RE (Eds.) Hormones and reproduction in fishes, amphibians and reptiles. New York, Plenum Press, 613p.

Joss JMP (1989) Gonadal development and differentiation in Alligator mississippiensis at male and female producing incubation temperatures. Journal of Zoology 218(4): 679687. doi: 10.1111/j.1469-7998.1989.tb05009.x 
Junqueira LCU, Bignolas G, Brentani RR (1979) Picrosirius Staining Plus Polarization Microscopy, a Specific Method for Collagen Detection in Tissues Sections. The Histochemical journal 11(4): 447-455. doi: 10.1007/BF01002772

Kiernan JA (1990) Histological and Histochemical Methods Theory and Practice. Frankfurt, Pergamon Press, $2^{\text {nd }}$ ed.

LANCE VA (1989) Reproductive-Cycle of the American Alligator. Integrative and Comparative Biology 29(3): 999-1018.

LESSMAN CA (1999) Oogenesis in nonmammalian vertebrates, p. 498-508. In: Knobil E, Neill JD (Ed.) Encyclopedia of reproduction. New York, Academic Press, vol. 2.

Lillie RD, Fullmer HM (1976) Histopathologic Technique and Practical Histochemistry. New York, Mac Graw-Hill Book Co., $4^{\text {th }}$ ed., 942p.

Lozano A, Ramírez-Bautista A, Uribe MC (2014) Oogenesis and ovarian histology in two populations of the viviparous lizard Sceloporus grammicus (Squamata: Phrynosomatidae) from the central Mexican Plateau. Journal of Morphology 275(8): 949-960. doi: 10.1002/jmor.20275

Magnusson We, Vliet KA, Pooley AC, Whitaker R (1989) Reproduction, p. 118-135. In: Ross CA (Ed.) Crocodiles and Alligators. Silverwater, Goldem Press.

Nogueira KO, Rodrigues SS, Araújo VA, Neves CA (2011) Oviductal Structure and Ultrastructure of the Oviparous Gecko, Hemidactylus mabouia (Moreau De Jonne's, 1818). Anatomical Record 294(5): 883-892. doi: 10.1002/ar.21375

NorRIS DO (2007) Vertebrate endocrinology. Tokyo, Academic Press, 550p.

Palmer BD, Guillette Jr LJ (1992) Alligators provide evidence for the evolution of the archosaurian mode of oviparity. Biology of Reproduction 46(1): 39-47.

Palmer BD, De Marco VC, Guillette Jr LJ (1993) Oviductal morphology and the eggshell formation in the lizard, Sceloporus woodi. Journal of Morphology 217(2): 205-217. doi: 10.1002/jmor.1052170208

Perkins JM, PaLMer BD (1996) Histology and functional morphology of the oviduct of an oviparous snake, Diadophis punctatus. Journal of Morphology 277(1): 67-79. doi: 10.1002/ (SICI)1097-4687(199601)227:1<67::AID-JMOR5>3.0.CO;2-M

Sever DM, Ryan TJ, Morris T, Patton D, Swafford S (2000) Ultrastructure of the Reproductive System of the Black Swamp Snake (Seminatrix pygaea). II. Annual Oviducal Cycle. Journal of Morphology 245(2): 146-160. doi: 10.1002/
1097-4687(200008)245:2<146::AID-JMOR5>3.0.CO;2-F

Stoker C, Rey F, Rodriguez H, Ramos JG, Sirosky P, Larriera A, Luque EH, Muño-de-Toro M (2003) Sex reversal effects on Caiman latirostris exposed to environmentally relevant doses of the xenoestrogen bisphenol A. General and comparative endocrinology 133(3): 287-296. doi: 10.1016/S00166480(03)00199-0

Stoker C, Beldomenico PM, Bosquiazzo VL, Zayas MA, Rey F, Rodriguez H, Munoz-De-Toro M, Luque EH (2008) Developmental exposure to endocrine disruptor chemicals alters follicular dynamics and steroid levels in Caiman latirostris. General and Comparative Endocrinology 156(3): 603-612. doi: 10.1016/ j.ygcen.2008.02.011

Tumkiratiwong P, Meesuk W, Chanhome L, Aowphol A (2012) Reproductive patterns of captive male and female monocled cobra, Naja kaouthia (Lesson, 1831). Zoological Studies 51(5): 692-700.

Uribe MC, Guillette JR LJ (2000) Oogenesis and ovarian histology of the American alligator Alligator mississippiensis. Journal of Morphology 245(3): 225-40. doi: 10.1002/10974687(200009)245:3<225::AID-JMOR4>3.0.CO;2-M

Van Nassauw L, Harrisson F, Callebaut M (1991) Localization of smooth-muscle markers in the ovaries of some ectothermic vertebrates. Anatomical Record 229(4): 439-446. doi: 10.1002/ ar.1092290402

VAN Voorhis BJ (1999) Follicular development, p. 376-389. In: KNobiL E, NeILL JD (Ed.) Encyclopedia of Reproduction. New York, Academic Press, vol. 2.

VERDADE LM (1995) Reproductive biology of the broadsnouted Caiman (Caiman latirostris) in Sao Paulo, Brazil, p. 57-79. In: Larriera A, Verdade LM (Eds.) The Conservation and Management of Alligators and Crocodiles from Latin America (in Spanish). Santo Tome, Fundacion Banco Bica.

Vieira S, Romero de Perez G, Ramýrez-Pinilla MP (2010) Ultrastructure of the ovarian follicles in the placentotrophic Andean Lizard of the genus Mabuya (Squamata: Scincidae). Journal of Morphology 271(6): 738-749. doi: 10.1002/ jmor.10830

WAKE MH (1985) Oviduct structure and function in nonmammalian vertebrates. Fortschrittie Zoologie 30: 427-435.

YANOSKY AA (1990) Natural history of broad-snouted Caiman (Caiman latirostris), a poorly known Alligatorine (1). Revue Francaise d'Aquariologie Herpetologie 17: 19-31.

Submitted: 22 April 2015

Received in revised form: 23 July 2015

Accepted: 11 August 2015

Editorial responsibility: Carolina Arruda Freire 